\title{
Agent architect
}

Any British architect who has signed a Planning or Building Control application, or a traditional form of building contract, has declared themselves to be acting as their client's agent. For those with a penchant for spy stories, signing oneself as an agent has, perhaps, always carried a momentary frisson of glamour. But, far from such fancies, the complexities of agency - as a branch of contract law - have long troubled legal minds. Although the law's struggles with agency have a good provenance, the idea has an even longer history in philosophy. Agency troubled Thomas Aquinas at least as much as it has troubled later philosophical thinkers, from Hegel and Marx to Pierre Bourdieu. Philosophically, agency comprises the capacity to act. It is not necessarily moral; and the capacity for agency is widespread - even inanimate objects or fictional characters, if they exert power, can be said to exercise agency. For Marx, and many subsequent sociologists and theorists, agency has collective and historical dimensions; it constitutes a dynamic experienced by individuals as much as exercised by them.

The philosophical idea of agency informed a recent conference jointly organised by AHRA (the Architectural Humanities Research Association) and the Sheffield School of Architecture. Alongside two other texts (by Açalya Allmer and Newton D'souza), this issue of arq includes papers from that event. They are introduced with a short perspective piece by 'the Agency' - a research group at the Sheffield school (pp. 109-110) - and recounted in a conference report by Stephen Cairns (pp. 105-108). The conference drew from a previous event, Alternate Currents, which was covered in arq 12.2. It sought to review the role of architects as agents, and the distance that role seems to place between architects and the end users of buildings. Many papers, including some that follow, questioned the merits of institutionalised professional culture, and the extent to which architects are able to act effectively with a political and social conscience. How are architects, as legal agents, able to act with moral agency?

This question is not, perhaps, as arcane as it might first sound. The power structures of the profession and the construction industry can have an immediate impact on people's lives. Indeed, the institutional structures given form by architecture can also exert much influence. Here, the philosophical problems of agency become architectural problems. They have the capacity for real and immediate impact. The role of the architect as agent, and architecture's capacity for agency, remain important issues for architectural research.

THE EDITORS 


\section{architectural research quarterly}

\section{Subscribe now for 2009}

Innovative in conception, unique in breadth and generously illustrated, this pace-setting quarterly publication from Cambridge University Press links, on a global scale, the worlds of architectural practice and research. arq regularly includes extensive peer-reviewed sections on design, history, theory, construction, environmental design, information technology and practice - as well as structures, urbanism and documents. These are supplemented by letters, reports, reviews, a directory of specialist research centers and consultancies and an annual index. Each issue opens with a leader and closes with insight, a personal end-piece. In its ten year history, arq has published work from all over the world: from Chile to Sweden and from Japan to the Netherlands - with a strong representation from the United Kingdom and United States. arq, like architecture itself, is all-embracing and written by and for both practitioners and academics. It provides an outlet for all those who wish to disseminate their work to an international audience.
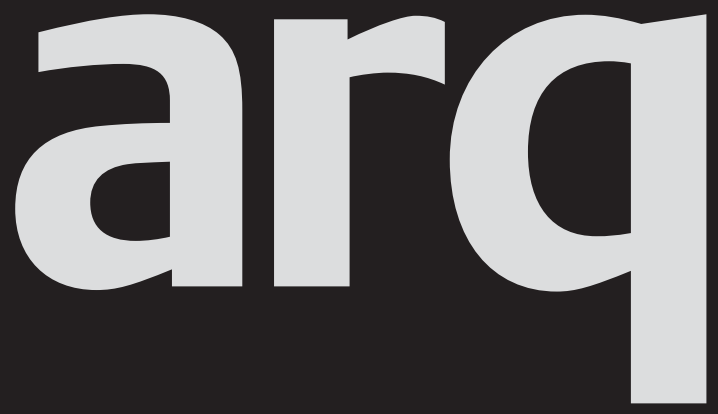

Please enter my subscription to arq: architectural research quarterly, volume 13, 2009 $\square$ E186/\$308 institutions print and electronic $\square E_{30} / \$ 50$ students print only

$\square$ £42/\$64 individuals print only

EU residents only. VAT may be payable at your local rate if not registered.

Our VAT registration number: GB 214141614 If registered, your VAT registration no:

Total subscription payment $£ / \$$ EU residents only, if not registered add VAT at appropriate rate

Canadian residents, add 7\% GST \$

Name

Total $\mathbf{E} / \mathbf{\$}$

Address

Payment enclosed

Cheque in sterling or US dollars

(payable to Cambridge University Press)

Credit Card - VISA | MasterCard | American Express (delete where applicable)

Card no

Expiry date

Signature

Photocopy this page and send your order to:

Journals Customer Services, Cambridge University Press, The Edinburgh Building, Cambridge, CB2 8RU, UK

$\mathrm{T}+44(0) 1223326070$

$\mathrm{F}+44(0) 1223315052$

E journals@cambridge.org

or in USA, Canada and Mexico send to:

Cambridge University Press, 32 Avenue of the

Americas, New York NY 10013-2473, USA

T (914) 9379600

F (914) 9374712

E journals_subscriptions@cup.org 